\title{
Correct Usage of the Term "Off-Label" in the Context of Corneal Cross-Linking [Letter]
}

\section{$L$ Jay Katz ${ }^{\mathrm{I}-3}$}

'Glaucoma Research Center, Wills Eye Hospital, Philadelphia, PA, USA;

${ }^{2}$ Department of Ophthalmology, Sidney Kimmel Medical College, Thomas Jefferson University, Philadelphia, PA, USA; ${ }^{3}$ Glaukos, San Clemente, CA, USA
Correspondence: $\mathrm{L}$ Jay Katz Glaukos, 229 Avenida Fabricante, San Clemente, CA, 92672, USA

Tel + I 949-48I-0459

Email ljkatz@willseye.org

\section{Dear editor}

As an ophthalmologist, a principal investigator, and the Chief Medical Officer at Glaukos, I greatly appreciate journals like Clinical Ophthalmology, which enable timely publication of novel research and emerging clinical techniques. In the recent article "Treatment of Keratoconus with WaveLight Contoura and Corneal CrossLinking Combined," Dr. Motwani raises a topical issue regarding the desire to incorporate learnings from our international colleagues into clinical practice within the landscape of United States regulatory approvals. ${ }^{1}$ When introducing new surgical techniques, transparency regarding the investigational status of drugs and medical devices is paramount: for patient safety, to protect physician practices, and in the ethical conduct of clinical research.

The author references United States Food and Drug Administration (US FDA) approval for corneal cross-linking, mistakenly referring to the combination procedure described in his article as "off-label." The term off-label refers to the unapproved use of an approved drug or medical device. To date, the only FDA-approved corneal cross-linking procedure for the treatment of progressive keratoconus and corneal ectasia following refractive surgery is the iLink platform (Photrexa Viscous $0.146 \%$ riboflavin 5 '-phosphate in $20 \%$ dextran ophthalmic solution, Photrexa $0.146 \%$ riboflavin 5 -phosphate ophthalmic solution and the KXL System, Glaukos), approved in 2016 under a new drug application (NDA 203324) for the drug/device combination product.

The term "off-label" refers to the use of an approved drug or medical device for uses or treatment indications that are not included in the product's approved labeling, within the practice of medicine. Neither the riboflavin ophthalmic solution nor the UV delivery system used in the cross-linking procedure described have received FDA approval, and therefore the procedure is not off-label- it is the use of an unapproved drug and medical device, which does not fall under the lawful practice of medicine. $^{2}$

Although the author indicates that no Institutional Review Board approval was required because this evaluation was a retrospective study, the surgical intervention utilized unapproved drug and device products, and therefore the investigational treatments should be performed within the framework of a prospective clinical study. Permission from the FDA is required to legally conduct a clinical study of an investigational drug product in the United States, such as under an investigational new drug application (IND). ${ }^{2,3}$ This requirement is in place, in part, to ensure that 
the drug is produced in accordance with good manufacturing practices (GMP). Circumventing this process not only threatens patient safety, but also presents legal risks and liabilities for medical professionals. ${ }^{2}$

While I appreciate the interesting topic of this research, I respectfully submit that as written, this study does not adhere to the standards for research ethics put forth by this journal and may mislead US ophthalmologists regarding the FDA approval status of the products described.

\section{Disclosure}

L Jay Katz is an employee of Glaukos as Chief Medical Officer. The author reports no other conflicts of interest in this communication.

\section{References}

1. Motwani M. Treatment of Keratoconus with WaveLight Contoura and Corneal Cross-Linking Combined. Clin Ophthalmol. 2021;15:2455-2472. doi:10.2147/OPTH.S303559

2. Godfrey BM, Shuren AW. Understanding On-Label, Off-Label, and Unapproved Products. CRST; October, 2020. Available from: https:// crstoday.com/articles/2020-oct/understanding-on-label-off-label-andunapproved-products. Accessed June 16, 2021.

3. U.S. Food and Drug Administration. "Off-Label" and Investigational Use of Marketed Drugs, Biologics, and Medical Devices Guidance for Institutional Review Boards and Clinical Investigators [Information Sheet]; 1998. Available from: https://www.fda.gov/regulatoryinformation/search-fda-guidance-documents/label-and-investigationaluse-marketed-drugs-biologics-and-medical-devices. Accessed June 16, 2021.

Dove Medical Press encourages responsible, free and frank academic debate. The content of the Clinical Ophthalmology 'letters to the editor' section does not necessarily represent the views of Dove Medical Press, its officers, agents, employees, related entities or the Clinical Ophthalmology editors. While all reasonable steps have been taken to confirm the content of each letter, Dove Medical Press accepts no liability in respect of the content of any letter, nor is it responsible for the content and accuracy of any letter to the editor.

Clinical Ophthalmology

\section{Dovepress}

\section{Publish your work in this journal}

Clinical Ophthalmology is an international, peer-reviewed journal covering all subspecialties within ophthalmology. Key topics include: Optometry; Visual science; Pharmacology and drug therapy in eye diseases; Basic Sciences; Primary and Secondary eye care; Patient Safety and Quality of Care Improvements. This journal is indexed on PubMed
Central and CAS, and is the official journal of The Society of Clinical Ophthalmology (SCO). The manuscript management system is completely online and includes a very quick and fair peer-review system, which is all easy to use. Visit http://www.dovepress.com/ testimonials.php to read real quotes from published authors. 